\title{
DIMENSI RELIGIUS DALAM PEMBELAJARAN SAINS DAN TEKNOLOGI: \\ Kasus Madrasah Aliyah Darul Ulum Jombang
}

\section{Hartono}

STAIN Purwokerto

Jl. Jend. A.Yani No. 40-A Purwokerto. Tlp.0281-635624

Email: hari_1572@yahoo.co.id

\begin{abstract}
ABSTRAK
Sains dan teknologi modern dianggap telah membawa tata nilai peradaban positivisme, materialisme dan keyakinan tentang "kematian Tuhan". Patut disayangkan, ternyata materi sains dan teknologi jenis itu yang justru kerap kali diajarkan pada sebagaian besar madrasah di Indonesia. Merespons kenyataan tersebut, saat ini dibutuhkan pembelajaran sains dan teknologi yang berperspektif pendidikan Islam, yakni yang mengekspresikan nilai-nilai tauhid (sains dan teknologi kesyukuran). Pembelajaran sains seperti ini mendorong manusia menjadi makhluk yang pandai bersyukur kepada Allah. Pembelajaran sains dan teknologi seperti ini tidak mengeksploitasi, tetapi mengelola dan memanfaatkan alam ini untuk kesejahteraan umat manusia dalam rangka membangun kesadaran diri mengenai besarnya kekuasaan Allah atas semua ciptaan-Nya. Pembelajaran sains dan teknologi seperti ini yang mestinya menjadi "model" pembelajaran sains di madrasah sebagai salah satu lembaga pendidikan Islam di tingkat dasar dan menengah. Sasaran kompetensi yang diharapkan terbangun pada diri peserta didik setelah memperoleh pembelajaran sains dan teknologi berperspektif pendidikan Islam adalah menguasai ilmu pengetahuan sekaligus meningkatkan keimanan dan ketaqwaan kepada Allah dengan segala ungkapan rasa syukurnya.
\end{abstract}

Kata Kunci: Pembelajaran, Sains dan teknologi, Dimensi religius

\begin{abstract}
Modern science and technology is considered contributing to the transfer of positivism, materialism and belief of "The Death of the God." However, factually this science and technology has become learning materials in madrasah. Therefore, it is found urgent learning science and technology on education Islamic perspective that reflects tawheed values or gratitude to God, or motivating people to be be thankful to God. It is the learning science and technology that do not exploit, instead cultivating, making use this nature for human walfare in order to develop the realization to God power on His all creatures. This learning science and technology "model" should be the centre of learning in madrasab (boarding school), so the expected competence students internalized is not only the mastery of knowledge (cognitive) but also gratitude to God (affective and psychomotor).
\end{abstract}

Keywords: Learning, Science and technology, Religious dimension 


\section{PENDAHLUAN}

Perkembangan Madrasah Aliyah Darul Ulum (MA DU) tidak dapat dilepaskan dari keberadaan Madrasah Aliyah Keagamaan (MAK) Darul Ulum. MAK Darul Ulum Jombang berdiri sejak tahun 1991 dan telah banyak meluluskan alumninya melanjutkan studi ke perguruan tinggi negeri umum maupun Islam dalam negeri maupun luar negeri. MAK Darul Ulum merupakan sebuah madrasah yang didesain khusus untuk "mencetak" siswa yang memiliki ilmu dan pengamalan agama yang mendalam dan menyeluruh. Perkembangan MAK yang tidak begitu menggembirakan, mendorong Pimpinan Majelis Pondok Pesantren Darul Ulum (PPDU) untuk menerima bantuan senilai Rp. 2.7 milliar untuk pembangunan gedung laboratorium dan isinya pada tahun 2005. Karena program Departemen Agama itu untuk penguatan sains dan teknologi, maka konsekuensinya MAK harus berubah menjadi MA (SMA) agar dapat mengakomodasi tujuan dari sang pemberi dana.

Departemen Agama Republik Indonesia bekerjasama dengan Islamic Development Bank (IDB) dalam Science and Technology Equity Program Phase -2 (STEP-2) memberikan bantuan kepada MA Darul Ulum berupa sejumlah laboratorium, antara lain laboratorium bahasa, komputer, fisika, kimia, biologi, dan keterampilan beserta bangunan gedung untuk ruang-ruang laboratorium tersebut. Karena bantuan yang begitu besar, seringkali kyai, guru, siswa, dan orang tua menyebut MA Darul Ulum sebagai MA STEP 2. STEP 2 merupakan kelanjutan dari STEP 1 yang telah berhasil mengembangkan MA Unggulan Serpong dan MA Unggulan Gorontalo. Melalui STEP 2 ini diharapkan lahir MA-MA unggulan baru yang menjadi simbol mutu pendidikan madrasah di Indonesia.

Visi dan misi MA Darul Ulum merupakan turunan dari moto Darul Ulum, yaitu "Mencetak Santri yang Berotak London dan Berhati Masjidil Haram". Berangkat dari moto tersebut dikembangkan visi dan misi MA Darul Ulum, yaitu "Beriman Tangguh, Handal dalam Sains-Teknologi, dan Berbudi Luhur". Untuk mewujudkan visi tersebut lembaga mengembangkan pola integrasi sains dan agama. Pola ini diharapkan mengintegrasikan dua keilmuan atau lebih menjadi satu keilmuan, satu rasa, satu dorongan, sehingga mewujudkan satu kepribadian tunggal/utuh, yaitu insan kaffah.

MA Darul Ulum mengklaim diri sebagai MA Unggulan. Hal ini dilakukan sebagai ikhtiar awal menjadi MA yang benar-benar unggulan sebagaimana telah dilakukan SMA Darul Ulum 2 yang kini telah berstandar internasional. Secara fisik, MA Darul Ulum layak disebut sebagai MA unggulan, karena fasilitas laboratorium fisika, kimia, biologi, komputer, dan bahasa sangat lengkap. Hal lain, MA ini didukung oleh guru-guru yang sesuai bidangnya dan sebagian besar bergelar magister. Tahun 2008, 2009, dan 2010 nilai rata-rata UAN (ujian akhir nasional) MA Darul Ulum mendapat kategori A. Sebagian besar lulusannya diterima di UIN, tetapi cukup banyak juga yang diterima di UGM, IPB, ITS, 
Unair, dan Unes. Beberapa diantaranya diterima dengan beasiswa penuh di perguruan tinggi Malaysia dan Pakistan.

MA Darul Ulum tergolong aktif mengikuti kegiatan perlombaan ilmiah pada tingkat kabupaten, propinsi maupun nasional. Pada tahun 2008 misalnya menjadi Finalis Lomba Karya Listrik dan Elektronika Kategori Web Desaign seJawa Timur di UNES Surabaya (satu-satu MA yang masuk finalis), tahun 2009 pada Madrasah Sains Expo (MSE) di Yogyakarta Juara I Kategori Bidang Desain Majalah, Juara II Kategori Karya Ilmiah Remaja, dan Juaran II Kategori Bidang Peragaan Alat Peraga. Belum lagi lomba-lomba di tingkat kabupaten MA Darul Ulum sangat mendominasi. Pada tahun 2009, MA Darul Ulum menyempurnakan diri dengan memperoleh akreditasi A.

Mulai tahun 2010, seleksi masuk MA Darul Ulum dilakukan oleh tim BPPT (Badan Pengkajian dan Penerapan Teknologi) sebagaimana juga dilakukan oleh sekolah-sekolah unggulan lain di PPDU. Melalui seleksi ini diharapkan diperoleh input yang bagus, sehingga nantinya mereka mampu berproses dengan baik. Melalui kerja sama dengan BPPT ini diharapkan mampu meningkatkan proses pembelajaran sains secara signifikan, sehingga MA Darul Ulum menjadi MA favorit. Sejauh ini, cukup banyak calon peserta didik yang tidak diterima di MA Darul Ulum, kemudian mereka dialihkan ke MAN di PPDU.

Salah satu hal yang menyebabkan MA Darul Ulum ini sejajar dengan SMA Darul Ulum 2 adalah implementasi pembelajaran sains yang diintegrasikan dengan agama. Efek psikologis pembelajaran ini adalah terbangunnya rasa syukur kepada Allah. Dengan pembelajaran ini peserta didik melihat bahwa segala sesuatu berasal dari Allah dan semuanya dapat dimanfaatkan oleh manusia demi kabaikan seluruh alam. Ini merupakan dimensi dasar bagi pengembangan sains berbasis rasa syukur (sains yang mensyukurkan). Sains yang berbasis konsep rasa syukur ini dikembangkan di MA Darul Ulum Jombang.

\section{PEMBAHASAN}

\section{Al-Qur'an sebagai Paradigma Psikologi Belajar}

Menurut Kuntowijoyo (1993) paradigma adalah cara berpikir (mode of thought) mengenai objek untuk menghasilkan sesuatu dengan cara tertentu pula. Al-Qur'an sebagai paradigma dapat dipahami sebagai cara pandang atau pemikiran yang didasarkan pada perspektif al-Qur'an. Berdasarkan Surat an-Nahl -78 digambarkan:

"Dan Allah telab mengeluarkan kamu dari perut ibumu dalam keadaan tidak mengetahui apa-apa. Kemudian Allah ciptakan bagimu pendengaran, penglihatan, dan hati agar kamu bersyukur".

Pada bagian awal ayat tersebut dijelaskan bahwa manusia secara hakiki adalah manusia yang tidak mengetahui apa-apa, tetapi memiliki potensi pendengaran, penglihatan dan hati. Dengan potensi-potensi tersebut diharapkan manusia dapat belajar, kemudian mengembangkan pengetahuannya, sehingga 
menjadi makhluk yang mengetahui (berilmu pengetahuan). Setelah mengetahui manusia harus mampu untuk bersyukur.

Secara psikologis manusia dapat belajar melalui pendengaran dan penglihatannya. Dengan pendengaran dan penglihatan manusia mencari dan menemukan informasi-informasi yang dibutuhkannya. Dengan informasi itu hati bekerja untuk memprosesnya menjadi pengetahuan, yaitu pengetahuan yang memungkinkan seseorang menjadi tahu dan bersyukur. Hal ini sesuai dengan fungsi hati yang dijelaskan dalam al-Qur'an, yaitu untuk memahami.

\section{Rasa Syukur yang Melibatkan Hati}

Pendengaran dan penglihatan harus dipahami secara luas. Pendengaran digunakan untuk mendengar segala sesuatu yang sifatnya perkataan (qauliyah) dan penglihatan digunakan untuk melihat segala sesuatu yang sifat nyata atau alam semesta (kauniyah). Hal yang bersifat perkataan dapat bersumber dari al-Qur'an, hadis, teori, atau konsep, sementara yang nyata (belum menjadi pernyataan) bersumber dari fenomena-fenomena atau kejadian-kejadian alamiah, psikologis, dan sosial. Hati akan memahami informasi yang diterimanya menjadi informasi baru dalam bentuk pengetahuan. Bagaimana kerja hati ini. Tentu saja, jika mengacu pada Surat al-'Alaq ayat 1, "Bacalah dengan nama Tubanmu yang menciptakan", maka informasi yang masuk harus dipahami beserta di dalamnya ada Sang Pencipta, yaitu Allah.

Apapun yang dilihat dan dibaca manusia belum secara nyata menunjukkan kehadiran Sang pencipta, sehingga wajar pemahaman yang bersifat umum (common sense) mengenai segala sesuatu tidak akan mampu menghadirkan Allah di dalam hatinya. Inilah salah satu ciri utama sains yang dipahami sebagian besar umat Islam. Hal ini wajar, karena sains yang ada saat ini masih bersumber dari Barat yang sekuler, sehingga sains pun menjadi sekuler. Karena itu, pemahaman atas informasi yang diterima oleh hati dapat dilakukan melalui mekanisme asimilasi dan akomodasi dalam istilah Piaget (Santrock, 2004). Asimilasi adalah keadaan pikiran manusia yang mencocokkan informasi yang masuk dengan struktur hati yang telah terbentuk. Informasi yang diterima akan disesuaikan dengan pengetahuan dasar yang dimiliki seseorang. Akomodasi adalah keadaan pikiran manusia yang memodifikasi struktur hati menyesuaikan dengan informasi yang masuk, sehingga informasi itu menjadi pengetahuan baru.

Bagaimana dengan dinamika sistem struktur hati ini, apakah statis atau dinamis? Struktur hati dapat dinamis, tetapi dalam batasan keseimbangan antara yang tetap dan berubah (dalam bahasa Piaget equilibrium). Dalam membentuk pengetahuan, seseorang harus mencapai keseimbangan sehingga tidak hanya memahami informasi yang masuk, tetapi juga mengembangkannya. Struktur hati yang mengakui Allah sebagai pencipta yang membaca dan dibaca. Pada bagian yang lain, struktur hati harus menjadikan informasi baru yang masuk sebagai bahan yang mesti dikembangkan mengikuti perkembangan dengan tetap berdasarkan pada struktur hati yang pertama. Apapun informasi yang masuk 
harus disesuaikan dengan struktur hati yang berparadigma surat al-'Alaq ayat 1, kemudian dikembangkan sesuai kebutuhan manusia menjadi pengetahuan baru. Karena pengetahuan ini menghadirkan kesadaran akan keberadaan Allah sebagai sumber pertama pengetahuan manusia, maka pengetahuan mesti melahirkan dimensi baru dalam diri orang yang mengetahuinya, yaitu rasa syukur. Syukur adalah keadaan hati yang menerima segala yang diterimanya sebagai akibat dari kebesaran-Nya. Yaitu, secara ontologis objek pengetahuan yang dipahami manusia adalah ciptaan Allah dan alat-alat epistemologis juga merupakan ciptaan Allah. Bahkan, semua yang ada adalah ciptaan-Nya.

\section{Dimensi Religius dalam Pembelajaran Sains dan Teknologi}

Sains semestinya dibangun dan dikembangkan untuk membantu manusia menjadi orang yang pandai bersyukur. Menggunakan istilah Said, ilmuwan berkebangsaan Malaysia, paradigma sains tersebut adalah sains kesyukuran. Menurut Said (2008) umat Islam membutuhkan paradigma sains yang mensyukurkan atau sains kesyukuran. Sebuah hirarki yang menggambarkan tingkatan kebutuhan umat Islam atas sains. Sains kesyukuran menjadi kebutuhan tertinggi bagi kehidupan manusia, karena dengan syukur manusia akan mendapat kebaikan. Allah telah menjelaskan dalam al-Qur'an:

"... barang siapa yang bersyukur, maka hal itu kebaikannya untuk dirinya sendiri ...” (QS. 27: 40). Dengan bersyukur dengan serta merta manusia akan mendapatkan kebaikan dari-Nya.

Syukur merupakan hirarki kebutuhan manusia tertinggi yang harus direalisasikan untuk menemukan kebaikan-kebaikan selanjutnya. Allah menegaskan "jika kamu bersyukur, niscaya akan Aku tambah nikmat dari atas langit dan dalam bumi'. Said (2008) memberikan makna pada firman di atas, bahwa (a) Allah akan bukakan ilmu pengetahuan untuk menaklukan langit dan bumi dan (b) Allah akan tambahkan rejeki dari sumber-sumber yang tidak disangka-sangka yang jauh dari jangkauan pancaindra manusia.

Syukur juga dapat diartikan sebagai pengakuan seseorang atas pemberian Allah. Syukur merefleksikan rasa terima kasih seseorang atas nikmat-nikmat Allah. Dalam bahasa sehari-hari syukur dapat diartikan sebagai terima kasih (AlHelaly, 2009). Syukur bukan sekedar pengakuan atas sesuatu yang diterima, tetapi juga pengucapan terima kasih yang direfleksikan dalam sikap dan tingkah laku. Syukur sebagai sikap dan tingkah laku memiliki kekuatan yang luar biasa bagi seseorang yang melakukannya.

Manusia bagaikan magnet dan setiap detail peristiwa yang dialaminya datang atas daya tariknya sendiri (Sentanu, 2007:48). Manusia akan menarik halhal sebagaimana yang dipikirkan atau dirasakan. Jika ia selalu bersyukur, maka ia sama halnya dengan menarik hal-hal yang positif (nikmat). Jika ia tidak mampu bersyukur (kufur), sama halnya ia menarik hal-hal yang negatif (azdab). Kerja filosofis sains yang berbasis rasa kesyukuran dapat digambarkan sebagai berikut: 


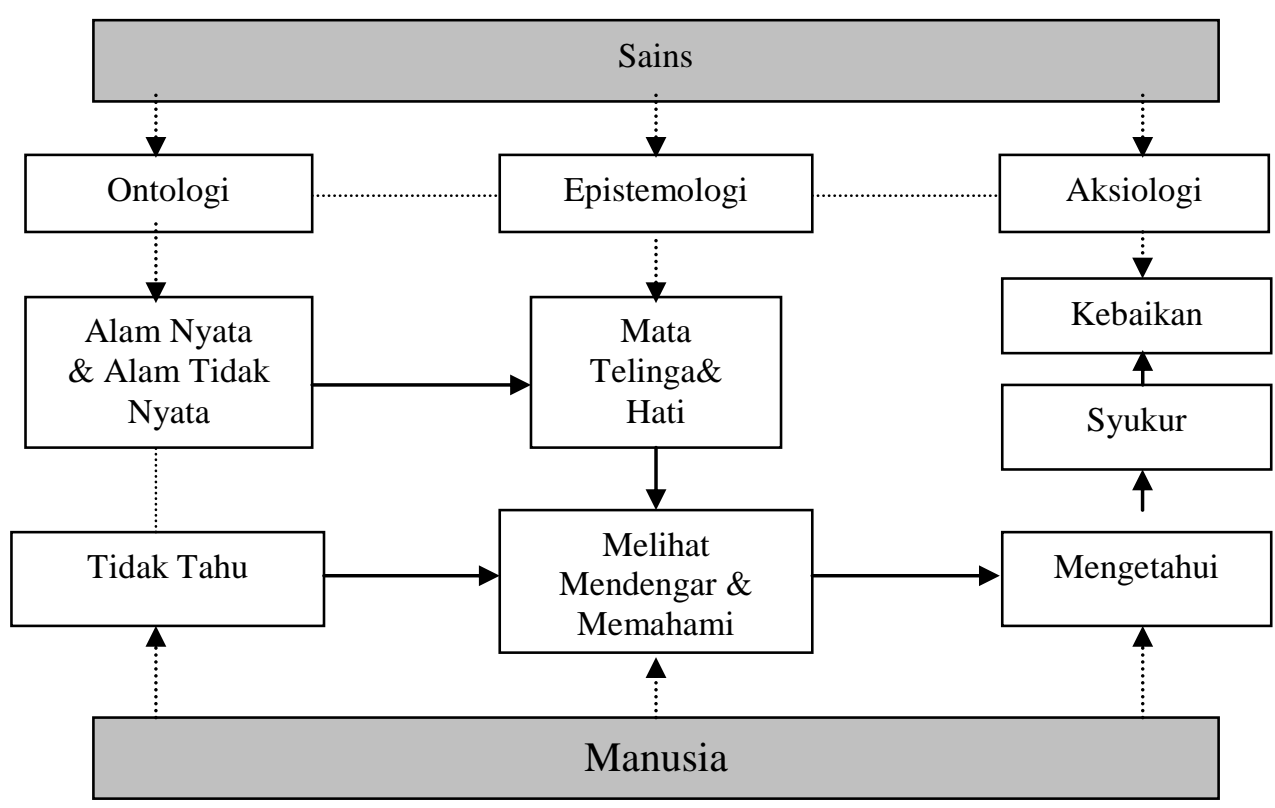

Bagan 1. Dimensi Religius dalam Pembelajaran Sains dan Teknologi

\section{Konsep Syukur dalam Pembelajaran Sains dan Teknologi}

Pembelajaran dalam implementasinya memiliki lima komponen, yaitu (a) tujuan; (b) materi; (c) metode; (d) media; dan (e) evaluasi. Dalam konteks ini akan digambarkan mengenai implementasi kelima komponen pembelajaran dengan menetapkan syukur sebagai konsep dasar materi pembelajaran.

\section{Syukur sebagai Tujuan Pembelajaran Sains dan Teknologi}

Tujuan pembelajaran mesti dikembangkan berdasarkan pada tujuan ilmu pengetahuan, karena pada dasarnya proses pendidikan adalah upaya membantu peserta didik menguasai ilmu pengetahuan (sains). Jika mengacu pada an-Nahl ayat 78 , maka tujuan sains adalah menjadi seseorang untuk bersyukur. Dengan demikian, tujuan pembelajaran adalah membantu peserta didik menguasai sains dan memiliki kemampuan untuk bersyukur.

Ketika seseorang menguasai sains semestinya pararel dengan perkembangan rasa syukur. Semakin tinggi pemahaman sainsnya, maka semakin cerdaslah ia dalam bersyukur.

\section{Syukur sebagai Materi Pembelajaran Sains dan Teknologi}

Dari kaca mata sains, surat an-Nahl ayat 78 menginspirasi pada dasar paradigma pengembangan keilmuan. Jika memperhatikan substansi ayat tersebut, maka pengembangan keilmuan harus memperhatikan faktor epistemologisnya, yaitu pendengaran, penglihatan, dan hati yang dimiliki manusia yang merupakan pemberian Allah. Kombinasi ketiganya menjadi bagian terpenting manusia membangun pengetahuannya, sehingga pengetahuan yang dibangunnya mampu 
menjadikan manusia untuk bersyukur. Sains mesti dikembangkan dengan tujuan membantu manusia untuk memahami alam ini sekaligus mensyukurinya.

Agar sains mampu menjadikan seseorang untuk bersyukur bagi yang menguasainya, maka sains harus dikembangkan secara seimbang antara penomena alam dan teori-teori. Fenomena alam menggambarkan realitas alam, baik alamiah maupun sosial yang biasa disebut sebagai ayat kauniyah. Teori-teori, terutama wahyu adalah teks-teks yang menggambarkan secara kata-kata (qauliyab) yang secara umum menggambarkan alam ini.

Sains kesyukuran mempresentasikan integrasi ayat kauniyah dan qauliyah. Fenomena alam harus dipahami menurut teori sains atau secara apa adanya dan menurut teks al-Qur'an. Kesesuain antara keduanya akan melahirkan pemahaman bahwa fenomena tersebut berproses secara alamiah yang prosesnya merupakan kehendak Allah. Pemahaman seperti ini akan mampu menjelaskan hubungan antara ciptaan (makhluk) dan sang pencipta (kholik), sehingga diharapkan mampu menjadi alternatif materi pembelajaran dalam pendidikan Islam.

\section{Metode Pembelajaran Sains dan Teknologi Berbasis Konsep Syukur}

Pembelajaran dapat mengedepankan metode ceramah atau diskusi sebagai usaha mengenalkan sesuatu melalui pendengaran peserta didik. Metode pengamatan tidak langsung (laboratorium) atau pengamatan langsung dipakai usaha pendidik mengenalkan sesuatu melalui penglihatan. Kombinasi pengenalan melalui penjelasan pendidik dan peserta didik melihat langsung faktanya memungkinkan peserta didik memperoleh gambaran secara teoretis atau tekstual maupun objeknya sendiri secara langsung atau manipulasi melalui laboratorium.

Pengalaman pembelajaran ini akan membawa peserta didik pada minimal dua bentuk kebenaran, yaitu kebenaran koherensi dan kebenaran korepondensi, sehingga peserta memiliki derajat keyakinan yang lebih tinggi. Hati fungsinya memahami apa yang didengar dan dilihatnya dengan paradigma al-'Alaq ayat 1, sehingga hati mampu membenarkan dan mengkontruksi pengetahuan baru berdasarkan perubahan-perubahan yang ada. Artinya, guru harus mengajak peserta didik berpikir mengenai objek yang dilihatnya dan penjelasan, baik secara teoritik maupun tekstual.

Dengan kata lain, pembelajaran harus mampu menyeimbangkan penggunaan fungsi pendengaran, penglihatan, dan hati agar peserta didik mampu memahami objek dengan baik, sekaligus mensyukurinya. Instrumen epistemologi yang berupa pendengaran, penglihatan, dan hati adalah instrumen bagi peserta didik dalam pembelajaran. Artinya, peserta didik menggunakan pendengaran dan penglihatan sebagai alat untuk mengetahui sesuatu yang nyata. Hati merupakan instrumen lanjutan setelah peserta didik menggunakan penglihatan dan pendengarannya. Apa yang dilihat dan didengar akan dipahami dengan hati. Pemahaman melalui hati akan terkuak sesuatu yang bersifat metafisik. 
Pengetahuan tentang objek yang yang bersifat fisik dan pemahaman atas objek metafisik inilah yang akan melahirkan rasa syukur pada diri peserta didik.

\section{Media Pembelajaran Sains dan Teknologi Berbasis Konsep Syukur}

Secara epistemologi, Allah telah menganugerahkan pendengaran, penglihatan, dan hati kepada manusia. Secara ontologis, Allah telah menciptakan alam dan segala isinya, baik yang tekstual maupun kontekstual, sehingga keberadaan alam ciptaan tersebut dapat dijadikan sebagai media pembelajaran. Dengan kata lain, ayat kauniyah dan qauliyah dapat dimanfaatkan sebagai media pembelajaran. Ketika mengajarkan materi hujan misalnya, guru dapat memanfaatkan fakta hujan berupa keadaan sebelum turun hujan, saat turun hujan, maupun setelah hujan sebagai media pembelajaran. Setelah siswa diberi penjelasan tentang hujan dengan menggunakan fakta alam, selanjutnya guru melengkapi penjelasannya dengan menguraikan ayat-ayat al-Qur'an terkait dengan proses turunnya hujan. Pola pembelajaran dan pemamfaatan media seperti itu, mampu memberikan kesan keterpaduan ayat kauniyah dan qauliyah (ilmu umum dan agama).

Hal yang perlu dipertimbangkan adalah ketika merencanakan dan menggunakan media adalah potensi yang dimiliki peserta didik, misalnya ketika peserta didik secara dominan memiliki potensi pendengaran, penglihatan, dan hati. Penggunaan media berdasarkan fungsi penglihatan, misalnya kejadian (jika kejadian selalu terulang), gambar, televisi, dan lain-lain. Fungsinya adalah meneguhkan kebenaran yang diterima melalui pendengaran, sehingga keyakinan atas kebenaran semakin kuat.

\section{Evaluasi Pembelajaran Sains dan Teknologi Berbasis Konsep Syukur}

Faktor yang sangat perlu mendapat perhatian ketika pendidik ingin melakukan evaluasi adalah tujuan pembelajaran. Artinya, pemilihan cara evaluasi harus memperhatikan tujuan pembelajaran yang telah ditetapkan. Misalnya, tujuan pembelajarannya adalah peserta didik mengetahui sesuatu pada ranah kognitif dan bersyukur pada ranah afektif-psikomotorik, maka evaluasi yang dilakukan harus menguji pengetahuan dan rasa syukur peserta didik. Jadi, pengembangan bentuk evaluasi tergantung pada tujuan pembelajaran itu sendiri.

Guru dapat melakukan evaluasi melalui tes tulis dan lisan, pengamatan secara terbatas di sekolah terhadap sikap dan tingkah laku peserta didik, atau melalui bimbingan konseling. Pilihan bentuk evaluasi sangat banyak, tetapi seringkali terbentur dengan keterbatasan waktu, dana, rasa malas, dan lain-lain.

Dalam konteks pendidikan nasional, seringkali inovasi pendidik dalam mengembangkan evaluasi pembelajaran terbentur adanya ujian nasional (UN) yang menentukan kelulusan peserta didik. UN sebagai bentuk evaluasi masih kognitif oriented, sehingga masih jauh dari harapan atau idealitas pendidikan Islam. Kelulusan siswa sama sekali tidak mempertimbangkan dan memperhatikan ranah afektif dan psikomotorik siswa. Akhlak mulia sebagai hasil belajar tidak menjadi jaminan bahwa siswa tersebut lulus. Malah sebaliknya, 
siswa yang kurang baik akhlaknya tiba-tiba lulus hanya karena mampu menjawab soal-soal UN. Permasalahannya adalah, seandainya pintar itu adalah hasil belajar, maka bagaimana dengan siswa yang tidak lulus tetapi akhlaknya sangat mulia? Apakah kemuliaan akhlak itu bukan dari hasil belajar? Kegiatan UN ini sangat jelas mereduksi dan menyederhanakan makna pendidikan secara utuh.

Kebijakan pemerintah soal UN ini merupakan tantangan yang mesti dijawab oleh insan pendidikan Islam. Jawaban tersebut bukan hanya dalam pengembangan sistem evaluasi pembelajaran melainkan yang jauh lebih penting adalah menyiapkan materi pembelajaran dengan konsep yang mencerminkan nilai-nilai Illahiah sekaligus ilmiah. Menurut al-Attas (1998) problem utama pendidikan Islam adalah materi pembelajaran. Materi pembelajaran saat ini masih didominasi oleh ilmu Barat yang sekuler. Karena itu, untuk mewujudkan tujuan pendidikan Islam dibutuhkan ilmu yang berparadigma Islami.

\section{Skema Pembelajaran Sains dan Teknologi Berbasis Konsep Syukur}

Prinsip-prinsip implementasi sains berbasis konsep syukur dalam komponen pembelajaran, yaitu:

1. Perencanaan dan pelaksanaan pembelajaran harus diawali dengan penetapan tujuan pembelajaran, yaitu integrasi keilmuan antara ilmu umum dengan ilmu agama (kognitif), iman (efeksi), dan amal shaleh (psikomotorik)

2. Untuk mencapai tujuan tersebut harus dirumuskan materi dengan ilmu yang bersumber dari teori (empirik/kauniyah) dengan al-Qur'an dan hadis (qauliyah) dalam satu kesatuan pemahaman.

3. Untuk mencapai kesatuan pemahaman dibutuhkan metode pembelajaran yang mampu membangun kesatuan pemahaman, yaitu telinga, mata, dan hati. Telinga untuk mendengar ayat qauliyah, mata untuk mengobservasi ayat kauniyah, dan hati untuk memahami keduanya. Ini tersurat dalam substansi Surat al-Alaq ayat 1. Pembelajaran tidak hanya mengedepankan pemaparan secara teoretik di kelas, tetapi harus menyeimbangkan dengan menggunakan metode pengamatan (observasi) terhadap alam nyata dan melakukan uji coba (eksperimen) di laboratorium agar terjadi keseimbangan antara pemahaman akal dengan perasaan hati nurani.

4. Ayat qauliyah dan kauniyah menyajikan gambaran, fenomena, dan fakta yang harus dieksplorasi peserta didik agar peserta didik memiliki pemahaman yang sempurna terhadap setiap materi pembelajaran.

5. Evaluasi harus menyentuh pada dataran pemahaman ilmu, keyakinan terhadap Sang Kuasa, dan perilaku peserta didik.

Secara keseluruhan pembelajaran sains berbasis konsep rasa syukur dapat digambarkan melalui skema berikut. 


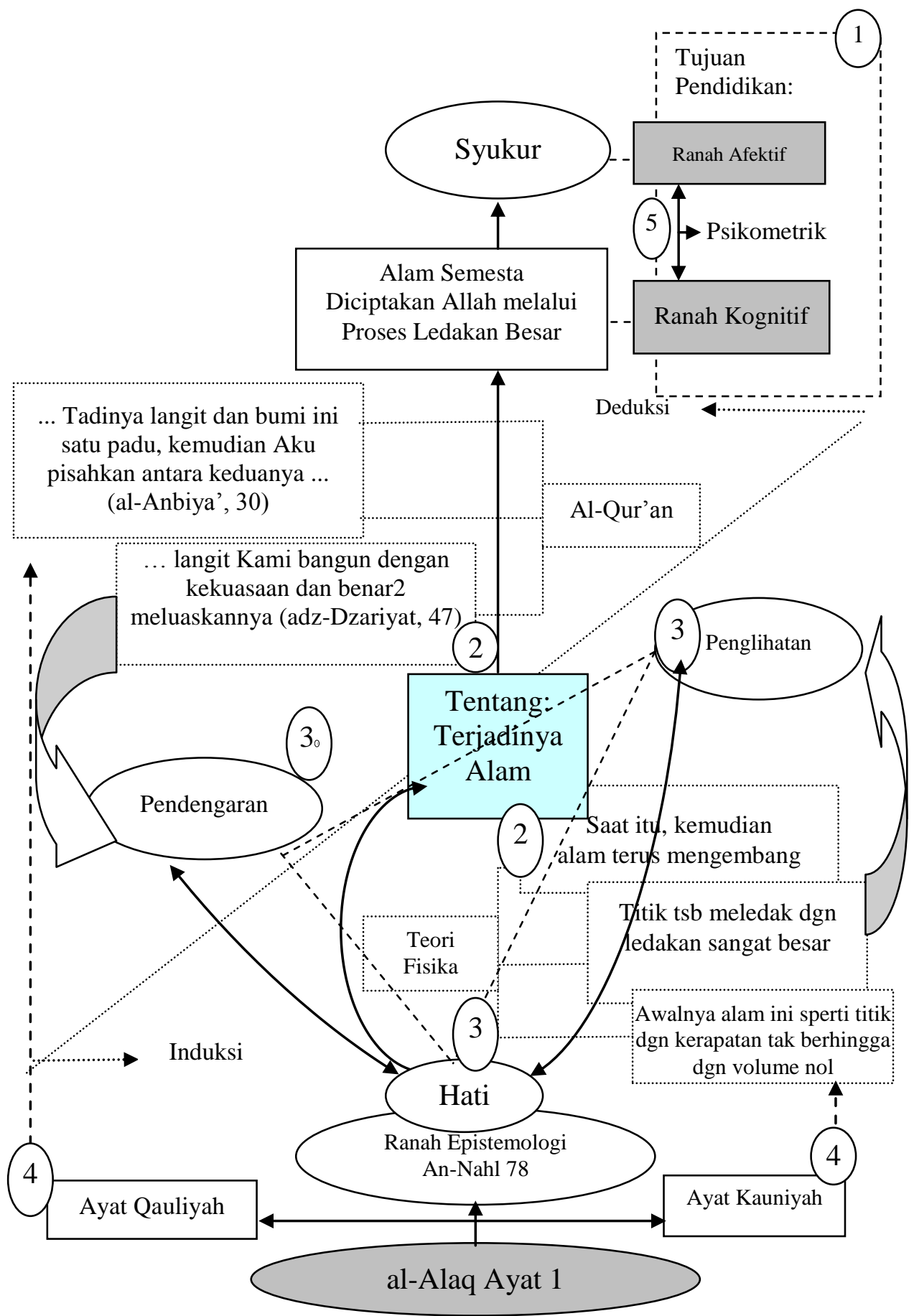

Bagan 2. Pola Implementasi Pembelajaran Sains dan Teknologi berbasis Konsep Rasa Syukur 
Keterangan komponen pembelajaran:
(1) Tujuan,
(2) Materi,
(3) Metode,
(4) Media,
(5) Evaluasi.

\section{SIMPULAN}

Metode pendidikan nilai Islam harus menunjukkan fakta-fakta atas suatu penjelasan dan menunjukkan penjelasan atas suatu fakta-fakta. Misalnya, jika guru akan menjelaskan tentang korupsi, guru tidak cukup mengatakan bahwa korupsi adalah tindakan yang diancam hukuman dan tidak bermoral. Ini adalah korupsi dalam penjelasan. Bagaimana korupsi dalam faktanya. Guru harus menunjukkan koruptor yang sedang dihukum, menunjukkan fakta penderitaan anak dan istri koruptor tersebut serta melihat efek kemiskinan dari tindakan koruptor. Melalui pengetahuan dan pemahaman mengenai korupsi secara menyeluruh ini peneliti yakini pendidikan tentang anti korupsi lebih efektif. Bahkan, dengan mengetahui dan memahami keseluruhan tentang korupsi, pendidikan tidak perlu mengatakan kamu jangan korupsi, karena korupsi merupakan tindakan tidak bermoral yang sangat merugikan banyak pihak. Proses mengetahui dan memahami ini adalah hasil kerja penglihatan, pendengaran, dan hati.

Hati ( $\left.f u^{\prime} a d\right)$ menurut banyak ulama dipahami sebagai akal. Akal dalam pengertian antara daya pikir dan daya qalbu (Shihab, 2002). Bagaimana ciri-ciri orang yang berakal itu. Al-Qur'an Surat Ali Imran ayat 190 telah menjelaskan bahwa "... tanda-tanda orang yang berakal (ulil albab)". Yaitu: "orang-orang yang mengingat Allah (yadrkuruna Allab) sambil berdiri atau duduk atau berbaring dan mereka memikirkan (yatafakekaruna) tentang penciptaan langir dan bumi ...” (QS. 3: 191). Yadzkurunallah adalah ranah hati (qalbu), sementara yatafakkaruna adalah ranah pikiran manusia. Pembelajaran harus mampu memaksimalkan potensi hati sekaligus pikiran peserta didik. Jika pembelajaran telah menyentuh hati dan pikiran peserta didik, maka peserta didik "... seraya berkata: "Ya Tuban kami, tiadalah Engkau menciptakan ini dengan sia-sia... (QS. 3: 191). Sebuah pengakuan akan kecerdasan dan ketelitian Tuhan dalam menciptakan segala sesuatu, sehingga semua yang Dia ciptakan tidak ada yang sia-sia.

Segala sesuatu yang diciptakan Tuhan pasti bermanfaat untuk kepentingan makhluk-Nya, ini nikmat dasar yang membuka pintu syukur manusia. Tugas pendidikan adalah mencerdaskan pendengaran, penglihatan, dan hati manusia. Orang yang cerdas pendengaran, penglihatan, dan hatinya akan menjadi individu yang cerdas dalam bersyukur. Segala sesuatu yang dilihat dan 
didengar harus diolah dalam hati dan pikiran. Dalam hati, yaitu mengakui bahwa yang kita lihat dan dengar adalah ciptaan Allah (ranah qalbu). Gambaran pikiran, yang kita lihat dan dengar dapat dirubah atau direkayasa untuk kepentingan manusia (teknologi). Ranah qalbu akan menunjukkan dimensi metafisika dan ranah pikiran menunjukkan dimensi fisika yang operasional dan teknik.

Metode ceramah, diskusi, eksperimen, dan observasi sebenarnya masih berada pada ranah mengetahui dan mendengar sesuatu yang operasional dan teknik. Bagaimana dengan ranah hati. Ranah hati adalah berusaha memahami sesuatu yang fisik itu secara metafisika, sehingga menghasilkan pemahaman atas sesuatu yang bersifat integratif, yaitu pengetahuan/ilmu integratif dan rasa syukur. Pengetahuan integratif adalah produk dari kerja pendengaran, penglihatan, dan hati. Pengetahuan inilah yang akan membangkitkan rasa syukur peserta didik.

Pembelajaran di madrasah, dalam hal ini Madrasah Aliyah di Indonesia, idealnya memiliki bobot mata pelajaran Pendidikan Agama Islam yang lebih banyak. Pembelajaran di madrasah masih menggunakan ilmu-ilmu sekuler Barat sebagai materi pembelajaran dan kecerdasan otak sebagai tujuan pembelajaran. Semestinya, madrasah di Indonesia harus memberikan ilmu-ilmu yang sesuai dengan paradigma Islam atau al-Qur'an sebagai materi pembelajarannya.

Paradigma itu dapat dikembangkan berdasarkan Surat an-Nahl ayat 78, yaitu mengembangkan ilmu melalui pendengaran, penglihatan, dan fu'ad, sehingga ilmu yang dikembangkan menjadikan seseorang menjadi semakin bersyukur kepada Allah. Dalam praktek pembelajarannya, pendengaran, penglihatan, dan fu'ad adalah potensi yang harus dikembangkan/dicerdaskan, sehingga produk akhir pembelajaran adalah kompetensi ilmu ilmiah yang Illahiah yang mensyukurkan peserta didik.

\section{DAFTAR PUSTAKA}

Ali, Moh. 2008. "Buku yang Khas Madrasah". Tabloid Republika Dialog Jumat (1 Pebruari 2008).

Bakar, O. 2008. Taubid dan Sains: Perspektif Islam tentang Agama dan Sains. Bandug: Pustaka Hidayah.

Daud, W.M.N.W. 1998. Filsafat dan Praktik Pendidikan Islam Syed M. Naquib Al-alAttas. Jakarta: Mizan.

Gholshani, M. 2003. The Holy Quran and The Sciences of Nature. terj. A. Effendi. "Filsafat Sains menurut al-Qur'an". Bandung: Mizan.

Hayat, Bahrul. 2008. "Mengoptimalkan Seluruh Kecerdasan Siswa". Tabloid Republika Dialog Jumat (1 Pebruari 2008).

2008. "Menguak Kembali Keagungan Tradisi Ilmiah Islam". Tabloid Republika Dialog Jumat (1 Pebruari 2008).

Mochtar, Affandi. 2008. "Tidak Ada Dikhotomi dalam Islam". Tabloid Republika Dialog Jumat (1 Pebruari 2008). 
Purwanto, A. 2008. Ayat-Ayat Semesta Sisi-Sisi Al-Qur-an yang Terlupakan. Bandung: Mizan Pustaka.

Republika. 2008. MA Plus Darul Ulum dapat Bantuan Rp. 2,7 Milyar. Selasa 17 Juni 2008.

Said, Z. 2008. Sains Kesyukuran: Teori Evolusi atau Hukum Absani Taqwim? Manusia bukan Mamalia, Hewan, atau Homosapiens. Kuala Lumpur: Percetakan TATT SDN BHD.

Sang, M.S. 2005. Educational Studies for KPLI, Teacher Professionalism Theme 3. Selangor: Multimedia-ES Resources Sdn. Bhd.

Santrock, John W. 2004. Educational Psychology. New York: McGraw-Hill Higher Education.

Shihab, Q. 2009. Tafsir Al-Misbab: Pesan. Kesan, dan Keserasian al-Qur'an. Jakarta: Lentera Hati.

Surya, M. 2000. Integrasi Taubid Ilmu dalam Sistem Pendidikan Nasional. Bandung: Penerbit Nuansa.

Tholkhah, Imam. dkk. 2004. Membuka Jendela Pendidikan Islam: Mengurai Akar Tradisi dan Integrasi Keilmuan Pendidikan Islam. Jakarta: Rajawali. 